ISSN 2077-1746. Вісник ОНУ. Біологія. 2015. Т. 20, вип. 2(37)

УДК: 612.823-053.88

DOI 10.18524/2077-1746.2015.2(37).55006

Т. С. Комшук, к.б.н.

ДВНЗ України «Буковинський державний медичний університет», кафедра анатомії людини імені М. Г. Туркевича, пр. Незалежності, 95/27, Чернівці, 58005, Україна, e-mail: rysnichuk@mail.ru

\title{
ГЕНДЕРНІ ВІДМІННОСТІ ЛІКВОРНОЇ СИСТЕМИ ГОЛОВНОГО МОЗКУ В ЛЮДЕЙ РІЗНОГО ВІКУ
}

На прикладі морфометричного дослідження магнітно-резонансних томограм осіб різного віку дано комплексну прижиттєву характеристику лікворної системи головного мозку людини. Вивчені гендерні особливості та міжпівкульна асиметрія проаналізованих показників.

Ключові слова: лікворна система, чоловіки, жінки, МРТ.

3 віком змінюються не тільки розміри головного мозку, але і співвідношення його структур і розмах їх індивідуальних відмінностей, який може розширюватися, залишатись без змін або навіть звужуватися [5]. На сучасному етапі за допомогою різних методів можна досліджувати лікворну систему головного мозку людини прижиттєво [7]. Обстеження вентрикулярної системи головного мозку, як і центральної нервової системи в цілому, успішно застосовують магнітно-резонансну томографію (МРТ) [11]. Певна кількість досліджень присвячена вивченню різних патологічних змін головного мозку саме новітніми методами $[8,12]$. Анатомічні та морфометричні аспекти становлення структур вентрикулярної системи головного мозку на різних стадіях постнатального періоду онтогенезу людини, які, власне, можна виявити сучасними методами отримання прижиттєвого зображення в умовах норми, вивчені недостатньо або не досліджені зовсім, а деякі з них залишаються дискусійними [4]. Дотепер не визначені показники МРТ окремих складових вентрикулярної системи головного мозку залежно від віку і статі людини. Це і спонукало дослідження вікових особливостей будови лікворної системи головного мозку людини [10]. Також вважаємо актуальним визначення прижиттєвих морфометричних характеристик вентрикулярної системи головного мозку у людей різного віку. Отримані морфометричні показники зможуть послужити еквівалентом анатомічної «норми» під час оцінки патологічних змін шлуночкової системи.

Мета дослідження полягала у проведенні морфометрії вентрикулярної системи головного мозку осіб різного віку та статі .

Робота виконана відповідно до основного плану НДР Буковинського державного медичного університету і являє собою фрагмент комплексної міжкафедральної теми «Закономірності перинатальної анатомії та ембріотопографії. Визначення статево-вікових особливостей будови і топографоанатомічних вза- 
ємовідношень органів та структур в онтогенезі людини» (№ державної реєстрації 0110U003078).

\section{Матеріал і методи дослідження}

Відповідно до рекомендацій VII Всесоюзної наукової конференції з питань вікової морфології, фізіології та біохімії (1965) усіх досліджуваних розділили на осіб юнацького віку - 11 обстежених; осіб II періоду зрілого віку - 51 обстежений; осіб старечого віку -7 обстежених. Проаналізовано 69 томограм осіб різного віку: шість чоловіків та п'ять жінок юнацького віку; двадцять п'ять чоловіків та двадцять шість жінок II періоду зрілого віку та три чоловіки та чотири жінки старечого віку. Для дослідження використано групи осіб, заміри в яких здійснювали за магнітно-резонансними томограмами без виражених патологічних змін головного мозку (таких, як аневризми, кісти, пухлини, тощо) iз застосуванням морфометричних методик згідно з рекомендаціями 3 енцефалометрії [4]. Обстеження проводились у відділенні променевої діагностики клінічного закладу «Рівненська обласна клінічна лікарня» на комп’ютерному томографі General Electric Healthcare «SignaMRI 1.5T» та у кабінеті магнітнорезонансної томографії клінічного закладу «Луцька міська клінічна лікарня» на комп'ютерному томографі Signa Profile Ce Medical Sistem - 1,5 Тл у стандартних анатомічних площинах (сагітальній, фронтальній і аксіальній).

Вивчено 13 морфометричних параметрів лікворної системи головного мозку, а саме розміри бічних, III та IV шлуночків головного мозку та довжину водопроводу в осіб обох статей різного віку.

При порівнянні парних показників (бічних шлуночків) вираховували коефіцієнт асиметрії $\left(\mathrm{K}_{\text {асм }}\right)$, який дорівнює різниці між показниками правого і лівого бічних шлуночків поділеної на суму показників правого і лівого шлуночків (у \%).

Результати опрацьовували за методами дискрипційної статистики 3 використанням t-критерію подібності-відмінності Стьюдента.

\section{Результати дослідження та їх обговорення}

Відомо, кожна вікова група характеризується певним співвідношенням об'єму головного мозку і об'єму лікворної системи і субарахноїдальних просторів. Після 40 років у більшості клінічно здорових людей за даними МРТ виявляється тонка лінія гіперінтенсивного сигналу навколо бічних шлуночків перивентрикулярний лейкоареоз [10]. 3 віковими змінами також пов'язують i наявність дрібних одиничних ішемічних осередків у зонах змішаного кровопостачання. Було показано, що в осіб без когнітивних порушень після 50 років об’єм великих півкуль зменшується на $2 \%$ за кожні десять років. У здорових літніх людей з віком збільшується об'єм шлуночкової системи і субарахноїдальних просторів щодо об'єму головного мозку. Оскільки головний мозок в нормі займає 87-92 \% внутрішньочерепного об'єму, то навіть незначне його 
зменшення призводить до істотної зміни об'ємного співвідношення з лікворними просторами [1].

Отримані морфометричні показники лікворної системи головного мозку можна використовувати як еквівалент анатомічної норми (див. таблицю).

Вивчення анатомії головного мозку здорових людей сприяє визначенню більш точної локалізації різних його структур в тривимірному просторі.

У більшості випадків при проведенні МРТ-дослідження на форму і розміри шлуночків звертається увага лише тоді, коли їх зміни явно виражені [3]. Спроби обчислити діапазон коливань розмірів шлуночків головного мозку в нормі робилися неодноразово, але за даними літератури отримані відомості досить суперечливі. Предметом спеціального вивчення є зміна стану лікворних просторів $з$ віком.

Найбільша мінливість у вивчених морфометричних показниках спостерігалася в бічних шлуночках.

Виявлено тенденцію до збільшення довжини переднього рога бічного шлуночка справа як в юнаків $\left(\mathrm{K}_{\mathrm{acm}}=1,0\right)$, так і у дівчат $\left(\mathrm{K}_{\mathrm{acm}}=5,2\right)$. При цьому довжина переднього правого і лівого рогів бічних шлуночків у чоловіків перевищує на 11,3 \% та 18,5 \% (відповідно) довжину переднього рога у жінок.

Міжпівкульна асиметрія ширини переднього рога бічного шлуночка спостерігалася в юнаків із збільшенням ширини переднього рога справа на 10,2 \% $\left(\mathrm{K}_{\text {aсм }}=5,4\right)$, і в дівчат із збільшенням даного показника зліва на $4,5 \%\left(\mathrm{~K}_{\text {асм }}=-\right.$ $2,4)$. При порівнянні ширини переднього рога бічного шлуночка між статями з'ясовано, що ширина переднього лівого рога бічного шлуночка в жінок перевищує на 15,9 \% ширину відповідного рога в чоловіків.

Довжина тіла бічного шлуночка в юнаків більша справа $\left(\mathrm{K}_{\mathrm{acm}}=1,5\right)$, а в дівчат - зліва $\left(\mathrm{K}_{\text {асм }}=1,5\right)$. При оцінюванні гендерних відмінностей довжина тіла бічного шлуночка як справа, так і зліва була більшою в юнаків на 11,3 \% та 18,5 \% (відповідно) ніж у дівчат.

При аналізі ширини тіла бічного шлуночка виявлено наступне: у юнаків справа $10,5 \pm 1,0$ мм, зліва - 12,0土1,9 мм, що на $12,5 \%$ більше, у дівчат справа $10,5 \pm 0,7$ мм, а зліва $-9,8 \pm 0,8$ мм, що на $6,6 \%$ менше. При порівнянні ширини тіла бічного шлуночка між статями спостерігалося збільшення показника в юнаків зліва на 22,5\%.

Міжпівкульна асиметрія довжини заднього рога бічного шлуночка спостерігалася у обох статей із збільшенням справа на $3,5 \%$ в юнаків $\left(\mathrm{K}_{\text {асм }}=1,9\right)$ та $4,9 \%$ у дівчат $\left(\mathrm{K}_{\mathrm{acm}}=2,5\right)$. При порівнянні довжини заднього рога бічного шлуночка між статями спостерігалося збільшення показника в юнаків справа на $3,5 \%$ та зліва — на 3,3\%.

Міжпівкульна асиметрія ширини заднього рога бічного шлуночка спостерігалася справа в юнаків на 9,5\% $\left(\mathrm{K}_{\text {асм }}=5,0\right)$. При порівнянні показника між статями виявлено збільшення його в дівчат справа на $6,7 \%$, зліва — на $17,4 \%$. 
氜

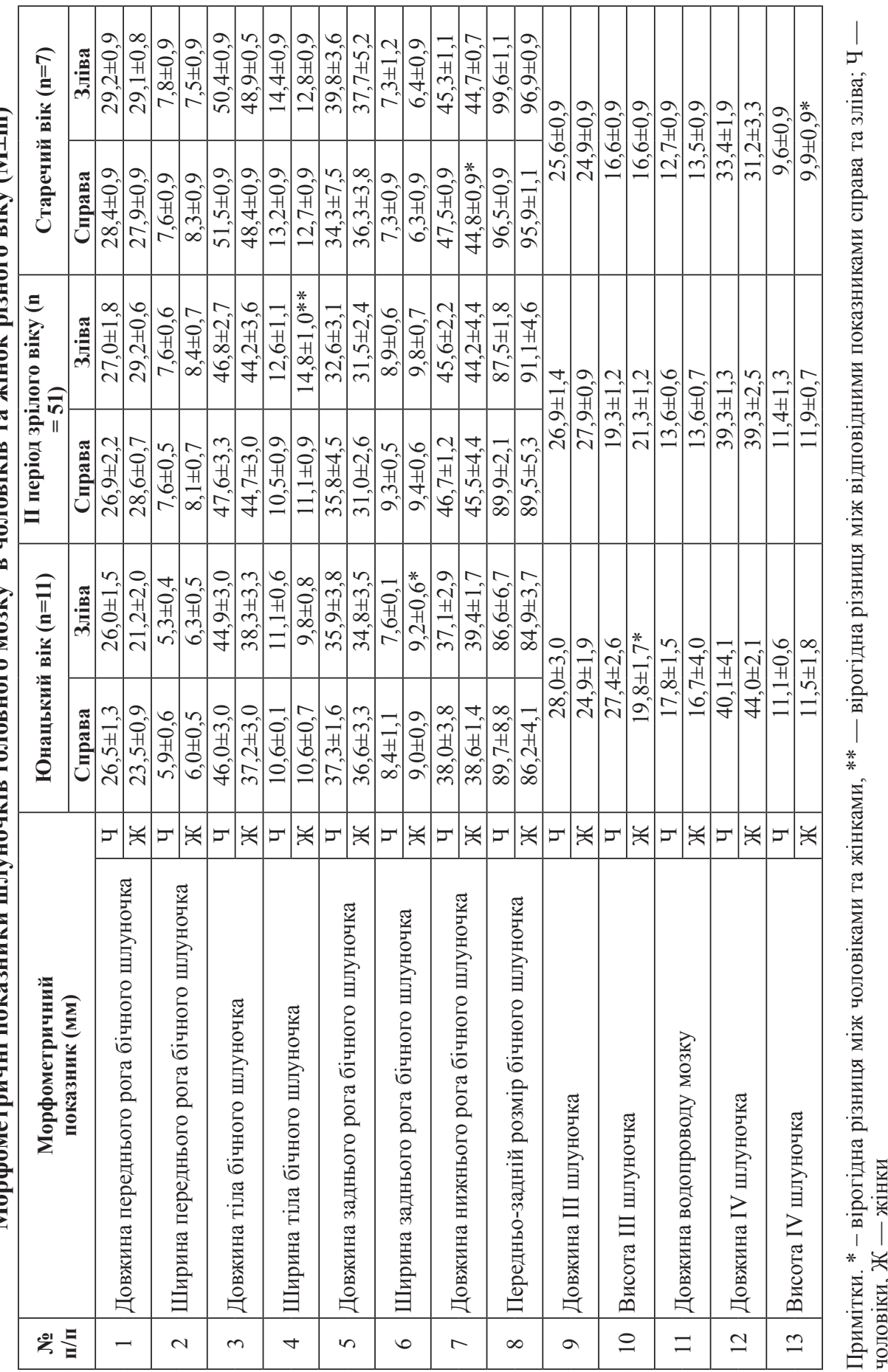


Міжпівкульна асиметрія нижнього рога бічного шлуночка траплялася в обох статей справа на $2,4 \%$ в юнаків $\left(\mathrm{K}_{\text {асм }}=1,2\right)$ та $6,2 \%$ у дівчат $\left(\mathrm{K}_{\mathrm{acm}}=1,0\right)$. При порівнянні показника між статями виявлено збільшення його в юнаків як справа, так і зліва на 3,7 \% та 6,2 \% відповідно.

Передньо-задній розмір бічного шлуночка був більшим справа як у юнаків, так і в дівчат на $3,5 \%\left(\mathrm{~K}_{\text {асм }}=1,8\right)$ та $1,5 \%\left(\mathrm{~K}_{\text {асм }}=0,8\right)$ відповідно. При вивченні гендерних особливостей показник був більшим у юнаків як справа, так і зліва на $3,9 \%$ та 2,0 \% відповідно.

При порівнянні довжини та висоти III шлуночка показника між статями виявлено вірогідне збільшення висоти ІІІ шлуночка в юнаків на 27,7 \%.

Довжина водопроводу в юнаків становила $17,8 \pm 1,5$ мм, у дівчат $16,7 \pm 4,0$ мм, що на $6,2 \%$ менше.

Проаналізовано довжину та висоту IV шлуночка, яка становила в юнаків $40,1 \pm 4,1$ та $11,1 \pm 0,6$ мм відповідно, а в дівчат $44,0 \pm 2,1$ та $11,5 \pm 1,8$ мм відповідно. При порівнянні показника між статями виявлено переважання довжини IV шлуночка в дівчат на $8,9 \%$.

У II періоді зрілого віку довжина переднього рога бічного шлуночка дещо більша зліва в чоловіків на 0,7 \% та на 2,1 \% у жінок. Спостерігалося збільшення довжини переднього рога зліва в жінок, порівняно з чоловіками. Ширина переднього рога бічного шлуночка більша в жінок порівняно з чоловіками. Також в осіб жіночої статі спостерігалося збільшення ширини переднього рога зліва порівняно $з$ правим. Довжина тіла бічного шлуночка менша в жінок порівняно 3 чоловіками та виявлена міжпівкульна асиметрія зі збільшенням показника справа в осіб обох статей: у чоловіків - на $6,1 \%\left(\mathrm{~K}_{\text {асм }}=0,9\right)$ і у жінок - на $5,6 \%\left(\mathrm{~K}_{\text {асм }}=0,6\right)$. Ширина тіла бічного шлуночка вірогідно більша в жінок як справа, так і зліва, і відмічалася асиметрія даного показника зі збільшенням зліва як у чоловіків $\left(\mathrm{K}_{\text {асм }}=-9,1\right)$, так і в жінок $\left(\mathrm{K}_{\mathrm{acm}}=-14,3\right)$.

Довжина заднього рога бічного шлуночка з обох боків менша в жінок, ніж у чоловіків. В осіб чоловічої статі спостерігалася асиметрія зі збільшенням довжини заднього рога зліва порівняно з правим $\left(\mathrm{K}_{\text {асм }}=4,7\right)$, а в жінок - навпаки $\left(\mathrm{K}_{\text {асм }}=-0,8\right)$.

Ширина заднього рога бічного шлуночка зліва більша в жінок порівняно 3 чоловіками $\left(\mathrm{K}_{\mathrm{acm}}=-2,1\right)$, а в чоловіків - навпаки $\left(\mathrm{K}_{\mathrm{acm}}=2,2\right)$.

Довжина нижнього рога бічного шлуночка збільшена справа на 2,1 \% у чоловіків $\left(\mathrm{K}_{\text {асм }}=1,2\right)$, та на $2,2 \%$ у жінок $\left(\mathrm{K}_{\mathrm{acm}}=1,5\right)$. Різниця відмічалася між показником у чоловіків.

Передньо-задній розмір бічного шлуночка становив у чоловіків справа $89,9 \pm 2,1$ мм, зліва $-87,5 \pm 1,8$ мм $\left(\mathrm{K}_{\text {асм }}=1,4\right)$, у жінок справа $-89,5 \pm 5,3$ мм,

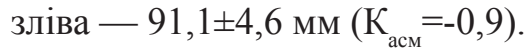

Довжина та ширина III шлуночка була більшою в жінок порівняно $з$ чоловіками. Довжина водопроводу та IV шлуночка не відрізнялася. Висота IV шлуночка переважала в жінок щодо показника у чоловіків. 
В осіб старечого віку встановлено, що довжина переднього рога бічного шлуночка є більшою зліва, як у чоловіків, так і в жінок на 2,7 \%, та 4,1 \% відповідно. Виявлена незначна міжпівкульна асиметрія даного показника в чоловіків $\left(\mathrm{K}_{\text {асм }}=-1,3\right)$, та в жінок $\left(\mathrm{K}_{\text {асм }}=-2,1\right)$.

Ширина переднього рога бічного шлуночка однакова справа і зліва в чоловіків, тоді як в осіб жіночої статі спостерігається збільшення показника справа на 9,6 \%. При порівнянні показника між статями виявлено тенденцію до його збільшення справа у жінок на 8,4\%.

Довжина тіла бічного шлуночка як справа, так і зліва, $є$ вірогідно меншою у жінок порівняно з чоловіками. Міжпівкульної асиметрії довжини тіла бічного шлуночка як у чоловіків, так і у жінок не спостерігається. Ширина тіла бічного шлуночка вірогідно більша у чоловіків зліва на 8,3 \%. У чоловіків ширина тіла більша як справа, так і зліва порівняно $з$ жінками.

Довжина заднього рога бічного шлуночка зліва в чоловіків є вірогідно більшою на $13,8 \%$ порівняно 3 правим $\left(\mathrm{K}_{\text {асм }}=-7,4\right)$, а в жінок всього на $3,7 \%$ ( $\mathrm{K}_{\text {асм }}=$ $-1,9)$. При порівнянні показника між статями виявлено збільшення його справа в жінок на 5,5 \% порівняно з протилежною статтю, а в чоловіків показник зліва більший на 5,3\%.

Ширина заднього рога бічного шлуночка однакова з обох боків в осіб обох статей. Відмічено певне збільшення показника в чоловіків, порівняно з жінками, як справа, так і зліва на 13,7 \% та 12,3 \% відповідно.

Довжина нижнього рога бічного шлуночка вірогідно більша справа в чоловіків $\left(\mathrm{K}_{\mathrm{acm}}=2,4\right)$. Також виявлена вірогідна статева відмінність показника як справа, так і зліва, зі збільшенням у чоловіків.

Передньо-задній розмір бічного шлуночка вірогідно більший у чоловіків, порівняно з жінками. При аналізі міжпівкульної різниці даної величини виявлено вірогідне збільшення передньо-заднього розміру бічного шлуночка зліва в чоловіків $\left(\mathrm{K}_{\text {асм }}=-1,6\right)$.

Довжина III шлуночка дещо переважає в чоловіків порівняно з жінками (на 2,7 \%). Статевих відмінностей у висоті III шлуночка не виявлено. Довжина водопроводу мозку, навпаки, $\epsilon$ вірогідно більшою в жінок, ніж у чоловіків. Довжина IV шлуночка має тенденцію до переважання в чоловіків на $6,6 \%$, а висота - у жінок, на 3,0 \%.

За даними досліджень В. В. Корниенко та ін. [6] об’єм шлуночкової системи залишається відносно постійним до 60 років, потім прогресивно збільшується, супроводжуючись асиметричним розширенням бічних шлуночків, більшою мірою в домінантному півкулі.

Характеризуючи процес вікових змін головного мозку, Braun S.M. [9] вказують, що розміри шлуночкової системи постійні і незмінні до 70 років, а потім 3'являється незначна симетричне розширення бічних шлуночків.

Пикалюк В. С. та ін. [2] підкреслює, що зі збільшенням окружності черепа, ширина третього шлуночка значно зменшується. У період з 16 до 20 років і 3 
50 до 57 років має місце фізіологічне незначне розширення бічних шлуночків, з 58 до 79 років виявляється більш виражене збільшення параметрів всієї шлуночкової системи головного мозку; у зв'язку з цим необхідно враховувати вікові коливання норми.

При проведенні дослідження встановлено збільшення розмірів структур шлуночкової системи мозку з віком у обох статей. Особливих коливань у розміpax зазнають бічні шлуночки. Так, у представників чоловічої статі довжина передніх рогів як справа, так і зліва збільшується у старечому віці на 6,7 та 11,3 \% відповідно. У жінок спостерігається збільшення дожини даних структур вже у II періоді зрілого віку як справа, так і зліва на 17,8 та 27,4 \% відповідно. Ширина переднього рога збільшується у обох статей вже в II періоді зрілого віку. У чоловіків даний показник справа збільшується на $22,4 \%$, а зліва - на $30,3 \%$, у жінок збільшується справа на 25,9 \%, а зліва - на 25,0 \%.

Довжина тіла бічного шлуночка збільшується з віком як у чоловіків, так і у жінок на 10,8 \% та 22,0 \% відповідно, міжпівкульної асиметрії не виявлено. Спостерігається зменшення довжини заднього рога з віком у чоловіків справа на $8,0 \%$. Довжина нижнього рога з віком зростає у чоловіків як справа, так і зліва на 20,0 \% та 18,1 \% відповідно. У жінок довжина нижнього рога також збільшується з віком з обох боків, справа на 13,8 \%, а зліва - на 11,9 \%. Передньо-задній розмір збільшується в обох статей у старечому віці. У чоловіків справа на 7,0 \%, зліва на 13,1 \%, у жінок - справа на 10,1 \%, зліва на $12,4 \%$. Висота III шлуночка поступово зменшується до старечого віку на 37,4 \% у чоловіків, та на 16,2 \% у жінок. Довжина водопроводу також має тенденцію до вкорочення у чоловіків на $28,7 \%$, а в жінок - на 19,2 \%. Довжина IV шлуночка зменшується з віком у представників обох статей: у чоловіків на $16,7 \%$, а в жінок - на 29,1 \%.

\section{Висновок}

Виявлений дослідженням статевий диморфізм вентрикулярної системи мозку в осіб різного віку проявляється двобічним переважанням у чоловіків довжини тіла бічного шлуночка, правобічним збільшенням довжини нижнього рога бічного шлуночка над аналогічними розмірами в жінок; водночас, у жінок переважають ширина переднього рога бічних шлуночків, довжина водопроводу мозку та висота IV шлуночка. 3 віком у представників обох статей зростають розміри бічних шлуночків, окрім довжини заднього рога. Розміри III i IV шлуночків та водопроводу навпаки зменшуються з віком у обох статей.

Перспективи подальших досліджень полягають в аналізі даних показників залежно від типу тілобудови обстежених та їх краніометричних показників. 


\section{Список використаної літератури}

1. Косоуров А. К. Возможности магнитно-резонансной томографии в морфологических исследованиях / А. К. Косоуров, Г. Д. Рохлин, И. А. Благова // Морфология. - 1999. - Т. 115, № 2. - С. 59-65.

2. Ликвор как гуморальная среда организма / [Пикалюк В. С., Бессалова Е. Ю., Ткач В. В. и др.]: под ред. проф. В. С. Пикалюка. - Симферополь: ИТ «АРИАЛ», 2010. - 192 с.

3. Лучевая диагностика опухолей головного и спинного мозга / Б. В. Гайдар [и др.]. - СПб.: Фолиант, 2006. $-336 \mathrm{c}$.

4. Мёллер Т. Б. Норма при КТ- и МРТ-исследованиях / Т. Б. Мёллер, Э. Райф; Пер. с англ.; Под общ. ред. Г. Е. Труфанова, Н. В. Марченко. - 2-е изд. - М.: МЕДпресс-информ, 2013. - 256 с.

5. Методика измерения боковых желудочков при МРТ-исследовании головного мозга человека / И. А. Андреев, А. Д. Халиков, Н. Р. Карелина [и др.]: матер. Всеросс. науч. конф., посвящ. 100-летию со дня рождения А. Н. Максименкова [«Анатомо-физиологические аспекты современных хирургических технологий»] (22-23 июля 2006 г.). - СПб., 2006. - С. 66.

6. MPT в диагностике нейрохирургических заболеваний головного мозга / В. В. Корниенко [и др.] // Клиническое применение магнитно- резонансной томографии. - 1991. - С. 31-32.11

7. Оиенка размеров боковых желудочков головного мозга на основе МРТ у мужчин зрелого возраста, имеющих различную форму черепа / И. А. Андреев, Н. Р. Карелина, Е. Н. Комиссарова [и др.] // Морфология. - 2008. - Т. 133, № 2. - С. 10.

8. Струкова С. С. Морфометрическая характеристика желудочков головного мозга у детей разного возраста по данным магнитно-резонансной томографии / С. С. Струкова: матер. докл. VIII конгр. Междунар. ассоц. морфологов (г. Орел, 15 сент. 2006 г.) // Морфология. - 2006. - Т. 129, № 4. - С. 119-120.

9. Braun S. M. Adult neurogenesis: mechanisms and functional significance / S. M. Braun, S. Jessberger // Development. - 2014. - V. 141. - P. 1983-1986.

10. Dimension of interventricular foramen and cerebral aqueduct according to different parameters examined by

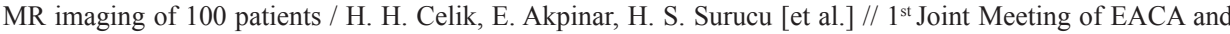
AACA (Graz, July 7-11, 2003). - Graz, 2003. - P. 153

11. Fast MR imaging of fetal central nervous system abnormalities / D. Levine, P. D. Barnes, R. R. Robertson [et al.] // Radiology. - 2003. - V. 229, № 1. - P. 51-61.

12. Incidental Findings on Brain MRI in the General Population / M. W. Vernooij, M. A. Ikram, L. Tangheet [et al.] // New Engl. J. Med. - 2007. - Vol. 357. - P. 1821-1828.

Стаття надійшла до редакції 03.06.2015

\section{T. С. Комшук}

ГВУЗ Украины «Буковинский государственный медицинский университет», кафедра анатомии человека имени Н. Г. Туркевича,

Черновцы, Театральная пл., 2, 58000, Украина

\section{ГЕНДЕРНЫЕ РАЗЛИЧИЯ ЛИКВОРНОЙ СИСТЕМЫ МОЗГА У ЛЮДЕЙ РАЗНЫХ ВОЗРАСТОВ}

\section{Резюме}

На примере морфометрического исследования магнитно-резонансных томограмм лиц разного возраста дана комплексная прижизненная характеристика ликворной системы головного мозга человека. Изучены гендерные особенности и межполушарная асимметрия проанализированных показателей.

Проанализированы 69 томограмм лиц разного возраста без выраженных патологических изменений головного мозга с применением морфометрических методик согласно рекомендациям по энцефалометрии. Изучено 13 морфометрических параметров ликворной системы головного мозга, а именно разме- 
ры боковых, III и IV желудочков головного мозга и длину водопровода у лиц обоего пола всех возрастов.

Исследованием обнаружен половой диморфизм желудочковой системы мозга у лиц разного возраста, который проявляется двусторонним преобладанием у мужчин длины тела бокового желудочка, правосторонним увеличением длины нижнего рога бокового желудочка над аналогичными размерами у женщин; одновременно у женщин преобладают ширина переднего рога боковых желудочков, длина водопровода мозга и высота IV желудочка. С возрастом у представителей обоих полов растут размеры боковых желудочков, кроме длины заднего рога. Размеры III и IV желудочков и водопровода наоборот уменьшаются с возрастом у обоих полов.

Ключевые слова: ликворная система, мужчины, женщины, МРТ.

\title{
T. S. Komshuk
}

SHEI Ukraine «Bukovina State Medical University», Department of Human Anatomy named M. G. Turkevich,

95/27, sq. Nezalezhnosti, Chernivtsi, 58000, Ukraine, e-mail: rysnichuk@mail.ru

\section{GENDER DIFFERENCES OF LIQUOR BRAIN SYSTEM IN PERSONS OF ALL AGES}

\begin{abstract}
Tomogramms analyzed 69 individuals of all ages without the expressed pathological changes in the brain using morphometric methods according to the recommendations of encephalometry. There were studied 13 morphometric parameters liquor system of the brain, namely the lateral dimensions, III and IV brain ventricles and the length of the fluid in both sexes of all ages.

The study found an increase in the size of structures ventricular system of the brain with age in both sexes. There were found special experiencing fluctuations in the size of the lateral ventricle.

There were discovered sexual dimorphism of ventricular system of the brain in people of all ages bilateral evident predominance of male body length of the lateral ventricle, right increasing length of the lower horn of the lateral ventricle of similar size in women; at the same time, women predominate width front horn of the lateral ventricles, water supply cord length and height of the IV ventricle. With age, both genders grow the size of the lateral ventricles than the length of the posterior horn. Dimensions III and IV ventricles and aqueduct conversely decrease with age in both sexes.
\end{abstract}

Keywords: liquor System, men, women, MRI. 